INFORMASI: Kajian Ilmu Komunikasi-ISSN (p) o126-065o; ISSN (e) 2502-3837

Vol. 48. No. 2 (2018). Pp.229-242. doi: https://doi.org/10.21831/informasi.v48i2.21382

\title{
MEDIA LITERACY AND SOCIAL MEDIA USAGE ANALYSIS IN COMMUNICATION AND NON-COMMUNICATION STUDENTS OF UNIVERSITY OF AMIKOM YOGYAKARTA
}

\author{
Dendy Suseno Adhiarso \\ dendysuseno@gmail.com \\ Mohammad Suyanto \\ msuyanto@amikom.ac.id \\ Universitas AMIKOM Yogyakarta
}

\begin{abstract}
Media literacyis the ability to understand, analyze, and deconstruct media images. The ability to do it is intended that the public as a media consumer becomes aware of how the media are built and accessed. The aims of this study are (1) to study the level of media literacy and social media usage patterns in communication and non-communication students. (2) to know the correlation between media literacy and social media usage patterns in communication and non-communication students. (3) comparing media literacy and social media usage patterns in communication and non-communication students. The population in this study were students of communication and noncommunication at the University of AMIKOM Yogyakarta which amounted to 656. The sample selected in this study 87 respondents who conducted with probability sampling technique with convenience sampling. Data obtained through the survey to respondents by spreading the questionnaire at the early of September 2017. Data processing and analysis is done by descriptive study, crosstab, spearman correlation and chi-square. The result of the research shows that (1) the level of media literacy of both communication and non-communication students is at the intermediate level, while social media usage patterns for communication and non-communication students is at a high level. (2) there is the significant correlation between media literacy and social media usage patternsin communication and non-communication students. (3) there is a difference between media literacy and social media usage patterns in communication and noncommunication students.
\end{abstract}

Keywords: Media Literacy, Social Media Usage Pattern, Communication Student, Non-Communication Student 


\title{
ANALISIS PENGGUNAAN LITERASI MEDIA DAN MEDIA SOSIAL DI MAHASISWA KOMUNIKASI DAN NON-MAHASISWA KOMUNIKASI UNIVERSITAS AMIKOM YOGYAKARTA
}

\begin{abstract}
Abstrak
Literasi media adalah kemampuan untuk memahami, menganalisis, dan mendekonstruksi citra media. Kemampuan untuk melakukannya dimaksudkan agar publik sebagai konsumen media menjadi sadar bagaimana media dibangun dan diakses. Tujuan dari penelitian ini adalah (1) untuk mempelajari tingkat literasi media dan pola penggunaan media sosial pada mahasiswa komunikasi dan non-komunikasi. (2) untuk mengetahui hubungan antara literasi media dan pola penggunaan media sosial pada mahasiswa komunikasi dan non-komunikasi. (3) membandingkan literasi media dan pola penggunaan media sosial pada mahasiswa komunikasi dan non-komunikasi. Populasi dalam penelitian ini adalah mahasiswa komunikasi dan non-komunikasi di Universitas AMIKOM Yogyakarta yang berjumlah 656. Sampel yang dipilih dalam penelitian ini adalah 87 responden yang dilakukan dengan teknik probability sampling dengan convenience sampling. Data diperoleh melalui survei kepada responden dengan menyebarkan kuesioner pada awal September 2017. Pengolahan dan analisis data dilakukan dengan studi deskriptif, crosstab, korelasi spearman dan chi-square. Hasil penelitian menunjukkan bahwa (1) tingkat literasi media mahasiswa komunikasi dan non-komunikasi berada pada tingkat sedang, sedangkan pola penggunaan media sosial untuk mahasiswa komunikasi dan non-komunikasi berada pada tingkat yang tinggi. (2) ada hubungan yang signifikan antara literasi media dan pola penggunaan media sosial pada mahasiswa komunikasi dan non-komunikasi. (3) ada perbedaan antara literasi media dan pola penggunaan media sosial pada mahasiswa komunikasi dan nonkomunikasi.
\end{abstract}

Kata Kunci: Literasi Media, Pola Penggunaan Media Sosial, Mahasiswa Komunikasi, Mahasiswa Non-Komunikasi

\section{INTRODUCTION}

The rapidly growing presence of social media has changed people's social lives. Particularly through gadgets such as smartphones, tablet and other thing that makes people easier to access various information through social media. The currentstate of society in filtering information (including in social media) sometimes passes through rationality (Youmans and York, 2012). This is because mass media are able to encourage their audiences to enjoy themselves and buy products, so the mass media can choose to present what is the most popular issues in society and sometimes regardless of whether it harasses logic, ruffles culture, dulls conscience or ignores the public interest.

According to research by We Are Social, a British media company that works with
Hootsuite, Indonesia the average person spending three hours 23 minutes a day to access social media. From the report entitled "Essential Insights Into the Internet, Social Media, Mobile, and E-Commerce Use Around The World," published on 30 January 2018, of a total population of Indonesia as much as 265.4 million people, an active user of social media to reach 130 million by penetration 49 percent. A total of 120 million Indonesian people using mobile devices, such as smartphones or tablets to access social media, with 45 percent penetration. Within a week, online activity on social media via smartphones reached 37 percent ("Digital in 2018: World's internet users pass the 4 billion mark - We Are Social," n.d.).

Meanwhile, based on the most downloaded apps, social media firm under 
Mark Zuckerberg dominates in the top three. Sequentially from the first position is WhatsApp, Facebook, Instagram, and freshly made social media followed by South Korea, Line. Based on the average traffic per month website, Facebook became the most visited social media with the achievements of more than 1 billion million visitors per month. Facebook, the average visitor, spent 12 minutes and 27 seconds to access social networking. 92 percent access Facebook via mobile with comparison rate by gender as much as 44 percent for women and 56 percent were male users. Facebook users are the 1824 age group dominated with a percentage of 20.4 percent were women, and $\mathbf{2 4 . 2}$ percent are men ("Riset Ungkap Pola Pemakaian Medsos Orang Indonesia - Badan Litbang," n.d.).

Hegemony Zuckerberg-owned company is also evident in the survey the most accessed social media in Indonesia based on the claim of the user. YouTube occupy the first position with a percentage of 43 percent, Facebook, WhatsApp, and Instagram followed in second and fourth position respectively. A total of 41 percent of social media users Indonesia claimed to use Facebook frequently, 40 percent often use WhatsApp, and 38 percent admitted to accessing Instagram frequently. While users who claimed to obtain the line as much as 33 percent frequently, and was in the fifth position. Globally, the total Internet users exceeded four billion users. For social media users, up 13 percent, with the year-onyear to 3.196 billion (Media, 2018).

Various information in social media will have a positive and negative impact, where the positive impact is the discretion to seek information and vice versa negative impact that is with the openness and spread of news that not for personal consumption and news that is not in accordance with reality (hoax). Not to mention other negative impacts such as: materilisme, culture of violence, culture to peek other personal live, even sexual maturity more quickly occur at the young age children(Fuchs, 2017a). The impacts of information disclosure in social media should be controlled if the audience have a good understanding of what information they need, how to filter both good and useless information and then how to address the information.

This concept is known as media literacy. Media literacy is the process of accessing, critically analyzing media messages and creating messages using tools(Potter, 2013). Media literacy is understanding of source, communication technology, code used, message generated, selection, interpretation and impact of the message(Silverblatt et al., 2014). The essence of this media literacy is the ability to provide a boundary between the real world and the virtual world created by the media. Thus the community is able to help the public to understand the healthy information and mass media negative and positive development can beaddress properly by audiences.

Students as part of educated society; whether studying communication or not, should have the ability to critically analyze media messages. Students are groups that look more susceptible to dependence on the internetthan othercommunitygroups(Brutus and Donia, 2010). This is because students are in the transition from late adolescence to young adults and they are experiencing the personality dynamics in forming identity, trying to live independently by breaking away from the dominance or influence of parents. This developmental phase then encourages students to form a social network through the use of social media

This study illustrates how the use of social media, among students in relation to media literacy. This research is expected to be the input of the communication colleges management in order to design the media literacy education. So the aim of this study are to (1) study the level of media literacy and social media usage in communication and non-communication students of Amikom Yogyakarta (2) to know the relationship between media literacy and social media usage pattern in communication and noncommunication students of Amikom Yogyakarta (3) to compare of media literacy and social media usage between 
communication and non-communication student of Amikom Yogyakarta.

\section{LITERATURE REVIEW}

\section{Media Literacy}

Media literacy is theability tounderstand, analyze, and deconstruct imaging media. The ability to do this is intended to allow the public as consumers of media (including children) becomes aware of how the press is constructed and accessed (Potter, 2010). The existence of mass media at this time was judged to have met by information or news that is frightening, such as violence, theft, sexual harassment, and so on. Even the mass media, the currently widely used as a disseminator of media pessimism message. As a result, the mass media it is very frightening for people. In developing countries, many found the fact that the expectations created by the communication messages in the mass media frustrating, because unlike the expectations described the press. To address the influence of the media as it is, at this moment developing thoughts about media literacy.

This study is an essential movement among advocacy organizations in developed countries aimed at controlling interests and the influence of the mass media in the lives of individuals, families, and communities as well as helping to design measures in dealing with the weight. In other words, this study supports the individual becomes aware of the role and function of the media. The fundamental purpose is to teach media literacy audiences and media users to analyze the messages conveyed by the mass media, consider the commercial and political objectives behind an image or media message, and investigate who is responsible for the word or idea described by words or pictures (Koltay, 2011). A media users who have a functional media literacy will seek to react and assess a media message with full awareness and responsibility.

Several types of existing media literacy, among others: (1) Print media are a type of old media in media literacy. In this case generally involves the use of text and images as well as specific illustrations to convey the message. Media is the most popular newspapers and magazines that still exists as a source of information. Until now, the print media as a source of information for the public or the public is still quite popular, especially newspapers. Although its existence began to decrease newspapers remain a media literacy materials favored by the people, both readers and writers. (2) Television is the type of media literacy not only displays text and images but also shows the words through sound and moving pictures or video illustrations. In this case the television into a complete package that is very accessible to the public as a source of information. (3) Digital / Internet (New Media): technological developments have an impact on media literacy. One is the birth of new media, namely digital media or the Internet. At this time the Internet is no longer something that is rare, but this time it is easily accessible anytime and anywhere. Besides the advantages of the Internet is a wide range of information access and unlimited (Kilian et al., 2012).

\section{Social Media}

Social Media is an online media, which provide convenience facilities for users to participate, share and create contents include blogs, social networks, wikis, forums, and virtual worlds. Blogs, social networks, and wikis are a form of social media that is most commonly used by people around the world (Kaplan and Haenlein, 2010). But others argue that social media is an online media that supports social interaction, and social media use web-based technology that transforms communication into interactive dialogue (Dabbagh and Kitsantas, 2012). Another definition of social media as a group of Internet-based applications that build on the ideological and Web 2.o technology and that allow the creation and exchange of usergenerated content (Berthon et al., 2012).

Social networking is a site where everyone can create a personal web page, then connect with friends to share information 
and communicate. Among another social networking site Facebook, Myspace, and Twitter. If the traditional media using the print media and broadcast media, the social media using the internet. Social Media invites anyone who is interested in participating by contributing and openly feedback, comment, and share information in a short time and infinite.

When the Internet and mobile phone technology has advanced, the social media also grow and develop rapidly. At this time for accessing facebook or twitter can be done anywhere and at any time, just by using a mobile phone. So fast people can access social media resulted in a significant phenomenon of the flow of information, not only in developed countries but also in Indonesia. Because the speed of social media is also starting to look replaces the conventional mass media's role in spreading the news.

The rapid development of social media is because everyone can have their press. If it is to have traditional media such as television, radio, or newspaper required significant capital and labor that much, then another case with social media. Social media users can access the Internet network, to which access is slow even though, without great expense, without expensive tools and conducted themselves without employees. Society as social media users can freely edit, add, modify, whether text, images, video, graphics, and various other content models.

Social media has characteristics, namely : The message conveyed is not only for one person but can be for many people, for example messages via SMS or internet, the message is free without having to go through a Gatekeeper, the message delivered tends to be faster than other media and the recipient of the message determines the time interaction(Fuchs, 2017b).

\section{Uses and Gratification Theory}

Thetheoryof useand satisfaction referred to as one of the most popular methods in the study of mass communication. This theory proposes that individual differences cause the audience search, use and respond to the media content is different, which is caused by a variety of social and psychological factors that differ between individuals and the audience (Ruggiero, 200o). This theory focuses attention on the audience as consumers of mass media and not on the message. This theory considered that the audience in the use of the goal-oriented press, are active at the same discriminatory (Smock et al., 2011). Audience rated find out their needs and is responsible for the selection of media. The theory of use and satisfaction began in 1940. When the researchers tried to find information about the motives on which the audience is listening to the radio and read the newspaper. They researched the radio and searched for information, why people are attracted to the program is broadcast, such as quizzes and serial radio drama. Looking for any information obtained satisfaction or what the motives of people are reading newspapers (Dimmick et al., 2007).

According to Herta Herzog is seen as the first began the study the use and satisfaction of this. He grouped the various reasons why people choose to consume radio and newspapers than education the role of desires and needs of the audience to the media selection (Katz, 2010). He discovered the existence of three types or types of gratification, namely: (1) Some people love soap operas because it serves as a means of emotional release by seeing and hearing other people's problems through the TV. (2) The audience can daydream (wishful thinking) to something that is not possible they won, they've gained enough satisfaction just by looking at the experience of others on the screen. (3) Some people feel they can learn from the soap opera program because if someone watches the program and something happens in his life, then he already knows what to do based on the 'lessons' obtained from the soap opera in question (Quan-Haase and Young, 2010).

To understand why people use the media, we can use the proposed Harold D Lasswell. He suggests three main functions of the press on society, namely: (1) The news serves to 
inform the audience about what is happening around them (surveying the environment). (2) Through the media the views are given to various things that happen, then the audience can grasp more accurately the surrounding environment (correlation of environmental parts). (3) Book functioning media to convey tradition and social values to the next generation of audiences (transmit social norms and customs). Besides, experts have developed four models of communication theory to explain how people use or consume media and effects (Smith and Lasswell, 2015).

\section{Individual Differences Theory}

SR theory then modified by Melvin DeFleur into the method or Individual Differences Individual Differences of Mass Communication. This is because according DeFleur media messages that contain certain stimuli and interact differently with the personal characteristics of the members of the audience. In this theory, DeFleur found media messages containing the stimulus produce different responses from the audience. This is caused by differences or characteristics of each, such as age, attitudes, interests, occupation, religion, and so on. Media messages containing certain stimuli that interact differently with the personal characteristics of the audience members (DeFleur and DeFleur, 2016).

In this theory have explicitly recognized the influence of psychological elements that interact with mass media exposure and effect. Thus there is a strong correlation between media messages with the audience response. The response or responses to those messages changed by psychological order. Therefore, the effect of the media to a mass audience was not uniform but varied. This is because they are individually different from one another in the psychological structure or way of life is formed by the environment in which the individual is growing and growing.

Individual Differences Theory includes two concepts, namely: structural own psychological and behavior of individuals. The mental structure of the individual will determine how individuals choose from the environment and how people give meaning to these stimuli. And two main factors influence individual behavior, that biological factors are heredity from parents and owned by each and socio-psychological factors (Gross and John, 2003). While the three components that include the socio-psychological factors, namely: the affective part is the emotional aspect, the cognitive part, namely the intellectual aspect relates to what is known human and conative components are functional aspects related to the customs and the will to act (Pike and Ryan, 2004). So the core of Individual Differences Theory is the view that the personal attitude and individual psychological organ will determine how individuals choose stimuli (stimulus) on the environment and how he gave meaning to these stimuli because everyone has their biological needs, learning experiences, and backgrounds. It is this difference that causes the influence of the mass media differently (Apperly, 2012).

\section{METHODS}

The type of this research is correlational study using quantitative approach. The population in this research is Communication and Non-Communication student of Amikom Yogyakarta, class of 2017 with total students 656 . The sample selected in this research is 87 respondents, which is done by probability sampling technique with convinence sampling. Instrument that being used in this research is media literacy measurement(Literat, 2014) and social media usage pattern(O'Keeffe and ClarkePearson, 2011). Data obtained through survey to respondents by spreading questionnaires in early September 2017. Data processing and analysis is done by descriptive analysis, crosstab, Spearman Correlation and chi square.

\section{RESULTS AND DISCUSSION}

Media literacy level and social media usage pattern among communication and non-communication students of University 
of Amikom Yogyakarta

The result of analysis of 87 questionaire about literacy level and social media usage pattern among communication and noncommunication students of University of Amikom Yogyakarta that have been collected is presented bellow :

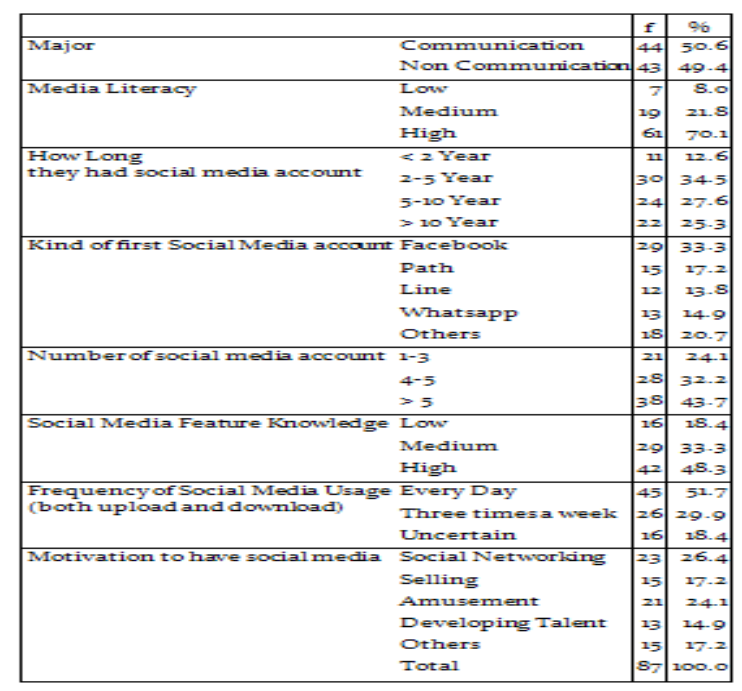

Table 1 show that participants of this research are consist of 44 communication stundets(50.6\%)and 43non-communications students $(49.4 \%)$. Most of participants have high media Literacy $(70.1 \%)$, most of them had social media account for 2-5 Years (34.5\%). Most of them had Facebook as first Social Media (33,3\%). Most of them had more than 5 social media accounts $(43,7 \%)$. Most of them have high knowledge about social media features $(48,3 \%)$. Most of them use social media every day $(51,7 \%)$ and use social media to have social network among their friends $(26,4 \%)$

Correlation of literacy level and social media usage pattern among communication and non-communication students of University Amikom of Yogyakarta

Analysis result of correlation of literacy level and social media usage pattern among communication and non- communication students of University of Amikom Yogyakarta is presented bellow :

Table 2. Correlation of Literacy Level And Social Media Usage Pattern Analysis Result

\begin{tabular}{|c|c|c|c|c|c|c|c|}
\hline & & & \multicolumn{2}{|c|}{ Media Literacy } & \multirow[b]{2}{*}{ High } & \multirow[t]{2}{*}{ Total } & \multirow[t]{2}{*}{$\begin{array}{c}\text { Spearman } \\
\text { Correlation } \\
\text { p-value }\end{array}$} \\
\hline & & & Low & Medium & & & \\
\hline \multirow{8}{*}{$\begin{array}{l}\text { How Long they had social media } \\
\text { account }\end{array}$} & $<2$ Year & Count & 5 & 5 & 1 & 11 & 0.000 \\
\hline & & $\begin{array}{l}\text { \% within } \\
\text { Media } \\
\text { Literacy }\end{array}$ & $71.4 \%$ & $26.3 \%$ & $1.6 \%$ & $12.6 \%$ & \\
\hline & 2-5 Year & Count & 2 & 14 & 14 & 30 & \\
\hline & & $\begin{array}{l}\text { \% within } \\
\text { Media } \\
\text { Literacy }\end{array}$ & $28.6 \%$ & $73.7 \%$ & $23.0 \%$ & $34.5 \%$ & \\
\hline & 5-10 Year & Count & 0 & 0 & 24 & 24 & \\
\hline & & $\begin{array}{l}\text { \% within } \\
\text { Media } \\
\text { Literacy }\end{array}$ & $0.0 \%$ & $0.0 \%$ & $39.3 \%$ & $27.6 \%$ & \\
\hline & > 10 Year & Count & o & o & 22 & 22 & \\
\hline & & $\begin{array}{l}\text { \% within } \\
\text { Media } \\
\text { Literacy }\end{array}$ & $0.0 \%$ & $0.0 \%$ & $36.1 \%$ & $25 \cdot 3 \%$ & \\
\hline $\begin{array}{l}\text { Kind of first Social Media } \\
\text { account }\end{array}$ & Facebook & Count & 4 & 6 & 19 & 29 & 0.130 \\
\hline
\end{tabular}


INFORMASI Kajian Ilmu Komunikasi Volume 48. Nomor 2. Desember 2018

\begin{tabular}{|c|c|c|c|c|c|c|c|}
\hline & & $\begin{array}{l}\text { \% within } \\
\text { Media } \\
\text { Literacy }\end{array}$ & $57.1 \%$ & $31.6 \%$ & $31.1 \%$ & $33.3 \%$ & \\
\hline & Path & Count & o & 5 & 10 & 15 & \\
\hline & & $\begin{array}{l}\text { \% within } \\
\text { Media } \\
\text { Literacy }\end{array}$ & $0.0 \%$ & $26.3 \%$ & $16.4 \%$ & $17.2 \%$ & \\
\hline & Line & Count & 1 & 4 & 7 & 12 & \\
\hline & & $\begin{array}{l}\text { \% within } \\
\text { Media } \\
\text { Literacy }\end{array}$ & $14.3 \%$ & $21.1 \%$ & $11.5 \%$ & $13.8 \%$ & \\
\hline & Whatsapp & Count & 1 & 4 & 8 & 13 & \\
\hline & & $\begin{array}{l}\text { \% within } \\
\text { Media } \\
\text { Literacy }\end{array}$ & $14.3 \%$ & $21.1 \%$ & $13.1 \%$ & $14.9 \%$ & \\
\hline & Others & Count & 1 & o & 17 & 18 & \\
\hline & & $\begin{array}{l}\text { \% within } \\
\text { Media } \\
\text { Literacy }\end{array}$ & $14.3 \%$ & $0.0 \%$ & $27.9 \%$ & $20.7 \%$ & \\
\hline \multirow[t]{6}{*}{ Number of social media account } & $1-3$ & Count & 7 & 12 & 2 & 21 & 0.000 \\
\hline & & $\begin{array}{l}\text { \% within } \\
\text { Media } \\
\text { Literacy }\end{array}$ & $100.0 \%$ & $63.2 \%$ & $3.3 \%$ & $24.1 \%$ & \\
\hline & 4-5 & Count & o & 7 & 21 & 28 & \\
\hline & & $\begin{array}{l}\text { \% within } \\
\text { Media } \\
\text { Literacy }\end{array}$ & $0.0 \%$ & $36.8 \%$ & $34.4 \%$ & $32.2 \%$ & \\
\hline & $>5$ & Count & o & o & 38 & 38 & \\
\hline & & $\begin{array}{l}\text { \% within } \\
\text { Media } \\
\text { Literacy }\end{array}$ & $0.0 \%$ & $0.0 \%$ & $62.3 \%$ & $43.7 \%$ & \\
\hline \multirow[t]{6}{*}{ Social Media Feature Knowledge } & Low & Count & 7 & 8 & 1 & 16 & 0.000 \\
\hline & & $\begin{array}{l}\text { \% within } \\
\text { Media } \\
\text { Literacy }\end{array}$ & $100.0 \%$ & $42.1 \%$ & $1.6 \%$ & $18.4 \%$ & \\
\hline & Medium & Count & o & 11 & 18 & 29 & \\
\hline & & $\begin{array}{l}\text { \% within } \\
\text { Media } \\
\text { Literacy }\end{array}$ & $0.0 \%$ & $57 \cdot 9 \%$ & $29.5 \%$ & $33.3 \%$ & \\
\hline & High & Count & $\mathrm{O}$ & $\mathrm{O}$ & 42 & 42 & \\
\hline & & $\begin{array}{l}\text { \% within } \\
\text { Media } \\
\text { Literacy }\end{array}$ & $0.0 \%$ & $0.0 \%$ & $68.9 \%$ & $48.3 \%$ & \\
\hline \multirow{5}{*}{$\begin{array}{l}\text { Frequency of Social Media Usage } \\
\text { (both upload and download) }\end{array}$} & Every Day & Count & o & o & 45 & 45 & 0.000 \\
\hline & & $\begin{array}{l}\text { \% within } \\
\text { Media } \\
\text { Literacy }\end{array}$ & $0.0 \%$ & $0.0 \%$ & $73.8 \%$ & $51.7 \%$ & \\
\hline & $\begin{array}{c}\text { Three times a } \\
\text { week }\end{array}$ & Count & o & 10 & 16 & 26 & \\
\hline & & $\begin{array}{l}\text { \% within } \\
\text { Media } \\
\text { Literacy }\end{array}$ & $0.0 \%$ & $52.6 \%$ & $26.2 \%$ & $29.9 \%$ & \\
\hline & Uncertain & Count & 7 & 9 & o & 16 & \\
\hline
\end{tabular}


Dendy Suseno Adhiarso dan Mohammad Suyanto, Media Literacy and Social Media Usage Analysis ...

\begin{tabular}{|c|c|c|c|c|c|c|c|}
\hline & & $\begin{array}{l}\text { \% within } \\
\text { Media } \\
\text { Literacy }\end{array}$ & $100.0 \%$ & $47 \cdot 4 \%$ & $0.0 \%$ & $18.4 \%$ & \\
\hline \multirow[t]{10}{*}{ Motivation to have social media } & $\begin{array}{c}\text { Social } \\
\text { Networking }\end{array}$ & Count & 7 & 11 & 5 & 23 & 0.000 \\
\hline & & $\begin{array}{l}\text { \% within } \\
\text { Media } \\
\text { Literacy }\end{array}$ & $100.0 \%$ & $57.9 \%$ & $8.2 \%$ & $26.4 \%$ & \\
\hline & Selling & Count & o & 8 & 7 & 15 & \\
\hline & & $\begin{array}{l}\text { \% within } \\
\text { Media } \\
\text { Literacy }\end{array}$ & $0.0 \%$ & $42.1 \%$ & $11.5 \%$ & $17.2 \%$ & \\
\hline & Amusement & Count & o & o & 21 & 21 & \\
\hline & & $\begin{array}{l}\text { \% within } \\
\text { Media } \\
\text { Literacy }\end{array}$ & $0.0 \%$ & $0.0 \%$ & $34.4 \%$ & $24.1 \%$ & \\
\hline & $\begin{array}{c}\text { Developing } \\
\text { Talent }\end{array}$ & Count & o & o & 13 & 13 & \\
\hline & & $\begin{array}{l}\text { \% within } \\
\text { Media } \\
\text { Literacy }\end{array}$ & $0.0 \%$ & $0.0 \%$ & $21.3 \%$ & $14.9 \%$ & \\
\hline & Others & Count & o & o & 15 & 15 & \\
\hline & & $\begin{array}{c}\text { \% within } \\
\text { Media } \\
\text { Literacy }\end{array}$ & $0.0 \%$ & $0.0 \%$ & $24.6 \%$ & $17.2 \%$ & \\
\hline \multirow[t]{2}{*}{ Total } & & Count & 7 & 19 & 61 & 87 & \\
\hline & & $\begin{array}{c}\text { \% within } \\
\text { Media } \\
\text { Literacy }\end{array}$ & $100.0 \%$ & $100.0 \%$ & $100.0 \%$ & $100.0 \%$ & \\
\hline
\end{tabular}

Table 2 above show us that media literacy level have significant correlation with how long students had social media account, it can be shown by $\mathrm{p}$-value $=0$,ooo that less than 0,05 . Media literacy level have no significant correlation with Kind of first Social Media account, it can be shown by p-value $=0,130$ that more than 0,05. Media literacy level have significant correlation with number of social media account, it can be shown by p-value $=0,000$ that less than 0,05 . Media literacy level have significant correlation with social media feature knowledge, it can be shown by $\mathrm{p}$-value $=0,000$ that less than 0,05 . Media literacy level have significant correlation with frequency of social media usage (both upload and download), it can be shown by p-value $=0$,ooo that less than o,05. Media literacy level have significant correlation with motivation to have social media , it can be shown by $\mathrm{p}$-value $=0,000$ that less than 0,05 .

Media literacy and social media usage difference between communication and non-communication student of University of Amikom Yogyakarta

Analysis result of media literacy and social media usage difference between communication and non communication student of University of Amikom Yogyakarta is presented bellow : 
Table 3. Media literacy and social media usage difference between communication and noncommunication student Analysis Result

\begin{tabular}{|c|c|c|c|c|c|c|}
\hline \multirow{2}{*}{\multicolumn{3}{|c|}{$\begin{array}{l}\text { Communication } \\
\text { Non Communication }\end{array}$}} & \multicolumn{2}{|l|}{ Major } & \multirow[b]{2}{*}{ Total } & \multirow{2}{*}{$\begin{array}{l}\text { Pearson Chi-Square } \\
\text { p value }\end{array}$} \\
\hline & & & & & & \\
\hline \multirow[t]{6}{*}{ Media Literacy } & \multirow[t]{2}{*}{ Low } & Count & o & 7 & 7 & 0.009 \\
\hline & & $\begin{array}{l}\text { \% within } \\
\text { Major }\end{array}$ & $0.0 \%$ & $16.3 \%$ & $8.0 \%$ & \\
\hline & \multirow[t]{2}{*}{ Medium } & Count & 8 & 11 & 19 & \\
\hline & & $\begin{array}{l}\text { \% within } \\
\text { Major }\end{array}$ & $18.2 \%$ & $25.6 \%$ & $21.8 \%$ & \\
\hline & \multirow[t]{2}{*}{ High } & Count & 36 & 25 & 61 & \\
\hline & & $\begin{array}{l}\text { \% within } \\
\text { Major }\end{array}$ & $81.8 \%$ & $58.1 \%$ & $70.1 \%$ & \\
\hline \multirow{8}{*}{$\begin{array}{l}\text { How Long they had } \\
\text { social media account }\end{array}$} & \multirow[t]{2}{*}{$<2$ Year } & Count & 5 & 6 & 11 & 0.549 \\
\hline & & $\begin{array}{l}\text { \% within } \\
\text { Major }\end{array}$ & $11.4 \%$ & $14.0 \%$ & $12.6 \%$ & \\
\hline & \multirow[t]{2}{*}{ 2-5 Year } & Count & 13 & 17 & 30 & \\
\hline & & $\begin{array}{l}\text { \% within } \\
\text { Major }\end{array}$ & $29.5 \%$ & $39.5 \%$ & $34.5 \%$ & \\
\hline & \multirow[t]{2}{*}{ 5-10 Year } & Count & 15 & 9 & 24 & \\
\hline & & $\begin{array}{l}\text { \% within } \\
\text { Major }\end{array}$ & $34.1 \%$ & $20.9 \%$ & $27.6 \%$ & \\
\hline & \multirow[t]{2}{*}{$>10$ Year } & Count & 11 & 11 & 22 & \\
\hline & & $\begin{array}{l}\text { \% within } \\
\text { Major }\end{array}$ & $25.0 \%$ & $25.6 \%$ & $25 \cdot 3 \%$ & \\
\hline \multirow{10}{*}{$\begin{array}{l}\text { Kind of first Social } \\
\text { Media account }\end{array}$} & \multirow[t]{2}{*}{ Facebook } & Count & 15 & 14 & 29 & 0.552 \\
\hline & & $\begin{array}{l}\text { \% within } \\
\text { Major }\end{array}$ & $34.1 \%$ & $32.6 \%$ & $33 \cdot 3 \%$ & \\
\hline & \multirow[t]{2}{*}{ Path } & Count & 6 & 9 & 15 & \\
\hline & & $\begin{array}{l}\text { \% within } \\
\text { Major }\end{array}$ & $13.6 \%$ & $20.9 \%$ & $17.2 \%$ & \\
\hline & \multirow[t]{2}{*}{ Line } & Count & 5 & 7 & 12 & \\
\hline & & $\begin{array}{l}\text { \% within } \\
\text { Major }\end{array}$ & $11.4 \%$ & $16.3 \%$ & $13.8 \%$ & \\
\hline & \multirow[t]{2}{*}{ Whatsapp } & Count & 6 & 7 & 13 & \\
\hline & & $\begin{array}{l}\text { \% within } \\
\text { Major }\end{array}$ & $13.6 \%$ & $16.3 \%$ & $14.9 \%$ & \\
\hline & \multirow[t]{2}{*}{ Others } & Count & 12 & 6 & 18 & \\
\hline & & $\begin{array}{l}\text { \% within } \\
\text { Major }\end{array}$ & $27 \cdot 3 \%$ & $14.0 \%$ & $20.7 \%$ & \\
\hline \multirow{6}{*}{$\begin{array}{l}\text { Number of social } \\
\text { media account }\end{array}$} & \multirow[t]{2}{*}{$1-3$} & Count & 2 & 19 & 21 & 0.000 \\
\hline & & $\begin{array}{l}\text { \% within } \\
\text { Major }\end{array}$ & $4.5 \%$ & $44.2 \%$ & $24.1 \%$ & \\
\hline & \multirow[t]{2}{*}{$4-5$} & Count & 11 & 17 & 28 & \\
\hline & & $\begin{array}{l}\text { \% within } \\
\text { Major }\end{array}$ & $25.0 \%$ & $39 \cdot 5 \%$ & $32.2 \%$ & \\
\hline & \multirow[t]{2}{*}{$>5$} & Count & 31 & 7 & 38 & \\
\hline & & $\begin{array}{l}\text { \% within } \\
\text { Major }\end{array}$ & $70.5 \%$ & $16.3 \%$ & $43.7 \%$ & \\
\hline
\end{tabular}


Dendy Suseno Adhiarso dan Mohammad Suyanto, Media Literacy and Social Media Usage Analysis ...

\begin{tabular}{|c|c|c|c|c|c|c|}
\hline \multirow{6}{*}{$\begin{array}{l}\text { Social Media } \\
\text { Feature Knowledge }\end{array}$} & \multirow[t]{2}{*}{ Low } & Count & 2 & 14 & 16 & 0.003 \\
\hline & & \begin{tabular}{|l|}
$\%$ within \\
Major
\end{tabular} & $4.5 \%$ & $32.6 \%$ & $18.4 \%$ & \\
\hline & \multirow{2}{*}{ Medium } & Count & 17 & 12 & 29 & \\
\hline & & $\begin{array}{l}\text { \% within } \\
\text { Major }\end{array}$ & $38.6 \%$ & $27.9 \%$ & $33.3 \%$ & \\
\hline & \multirow[t]{2}{*}{ High } & Count & 25 & 17 & 42 & \\
\hline & & \begin{tabular}{|l|} 
\% within \\
Major
\end{tabular} & $56.8 \%$ & $39.5 \%$ & $48.3 \%$ & \\
\hline \multirow{6}{*}{$\begin{array}{l}\text { Frequency of Social } \\
\text { Media Usage (both upload } \\
\text { and download) }\end{array}$} & \multirow[t]{2}{*}{ Every Day } & Count & 32 & 13 & 45 & 0.000 \\
\hline & & \begin{tabular}{|l|} 
\% within \\
Major
\end{tabular} & $72.7 \%$ & $30.2 \%$ & $51.7 \%$ & \\
\hline & \multirow{2}{*}{$\begin{array}{l}\text { Three times } \\
\text { a week }\end{array}$} & Count & 8 & 18 & 26 & \\
\hline & & \begin{tabular}{|l|} 
\% within \\
Major
\end{tabular} & $18.2 \%$ & $41.9 \%$ & $29.9 \%$ & \\
\hline & \multirow[t]{2}{*}{ Uncertain } & Count & 4 & 12 & 16 & \\
\hline & & \begin{tabular}{|l|}
$\begin{array}{l}\text { \% within } \\
\text { Major }\end{array}$ \\
\end{tabular} & $9.1 \%$ & $27.9 \%$ & $18.4 \%$ & \\
\hline \multirow{10}{*}{$\begin{array}{l}\text { Motivation to have social } \\
\text { media }\end{array}$} & \multirow{2}{*}{\begin{tabular}{|l|} 
Social \\
Networking
\end{tabular}} & Count & 10 & 13 & 23 & 0.001 \\
\hline & & \begin{tabular}{|l|} 
\% within \\
Major
\end{tabular} & $22.7 \%$ & $30.2 \%$ & $26.4 \%$ & \\
\hline & \multirow[t]{2}{*}{ Selling } & Count & 5 & 10 & 15 & \\
\hline & & \begin{tabular}{|l|} 
\% within \\
Major
\end{tabular} & $11.4 \%$ & $23.3 \%$ & $17.2 \%$ & \\
\hline & \multirow[t]{2}{*}{ Amusement } & Count & 14 & 7 & 21 & \\
\hline & & \begin{tabular}{|l|} 
\% within \\
Major
\end{tabular} & $31.8 \%$ & $16.3 \%$ & $24.1 \%$ & \\
\hline & \multirow{2}{*}{$\begin{array}{l}\text { Developing } \\
\text { Talent }\end{array}$} & Count & 12 & 1 & 13 & \\
\hline & & $\begin{array}{l}\text { \% within } \\
\text { Major }\end{array}$ & $27 \cdot 3 \%$ & $2.3 \%$ & $14.9 \%$ & \\
\hline & \multirow[t]{2}{*}{ Others } & Count & 3 & 12 & 15 & \\
\hline & & $\begin{array}{l}\text { \% within } \\
\text { Major }\end{array}$ & $6.8 \%$ & $27.9 \%$ & $17.2 \%$ & \\
\hline \multirow{2}{*}{\multicolumn{2}{|c|}{$\begin{array}{l}\text { Total } \\
\text { \% within Major }\end{array}$}} & Count & 44 & 43 & 87 & \\
\hline & & $100.0 \%$ & $100.0 \%$ & $100.0 \%$ & & \\
\hline
\end{tabular}

Table 3 above show us that media literacy level of communcation students and non- communications students have significant difference, it can be shown by Pearson Chi-Square $\mathrm{p}$ value $=0,009$ that less than 0,05. How long students had social media account of communcation students and non- communications students have no significant difference, it can be shown by Pearson Chi-Square $\mathrm{p}$ value $=0,549$ that more than 0,05 . Kind of first Social Media account of communcation students and non- communications students have no significant difference, it can be shown by Pearson Chi-Square $\mathrm{p}$ value $=0,552$ that more than 0,05 . Number of social media account of communcation students and non- communications students have significant difference, it can be shown by Pearson Chi-Square $\mathrm{p}$ value $=0,009$ that less than 0,05 . Social media feature knowledge of communcation students and noncommunications students have significant difference, it can be shown by Pearson ChiSquare $\mathrm{p}$ value $=0,003$ that less than 0,05 . Frequency of social media usage (both upload and download) of communcation students and non-communications students have significant difference, it can be shown by Pearson Chi-Square $\mathrm{p}$ value $=0,000$ that less than 0,05. Motivation to have social media of communcation students and noncommunications students have significant difference, it can be shown by Pearson ChiSquare $\mathrm{p}$ value $=0,001$ that less than 0,05 . 
In accordiance with this research finding, Baymstudied social interactions of college students across all media(Baym et al., 2007). Their results indicated that $64 \%$ still prefer face-to-face interaction, $18.4 \%$ prefer the telephone, and only $16.1 \%$ prefer the internet for making social contacts. The internet interactions reported showed that e-mail was by far the most dominant form of contact, followed by chat and instant-messaging. Of the 51 participants in the study, 49 reported conducting their social life contacts through at least two, and often three, methods on any given day(Baym, 2015). Similarly, one study reported that over $27 \%$ of young adults used a social networking site every day in 2009 (Lenhart et al., 2010). Social network sites help fulfill communication needs and wants. It is a convenient method of communication and provides the ability to stay connected with friends and family, but on the users own rate and time(Urista et al., 2009). Users can manage their interactions within their own schedule by choosing when they want to read and respond. The internet communication is a solitary activity usually done alone. However, it is efficient because it is a one-tomany method of communication that allows users to quickly spread information.

Besides of the above data, it can be seen that the level of media literacy, both students of communication and non-communication turned out to be in moderate levels, to say that the level of reading habit or find the truth of the information still being mediocre. When it should be at the level of the student's education has to be aware of and understand the improvement of media literacy as a filter to digestand appreciateevery bit of information, as well as knowing how to anticipate a wide range of information hoaxes. Moreover, students of communication in everyday life are very familiar with the use of social media as a source of information. However, if viewed from the level of use of social media that there were no differences between students of communication and non-communication are at a high level. This shows that regarding interest and habit in using social media, both students of communication and non- communication student both have a high level.

Another thing that can be seen from the results of this study is a significant relationship between media literacy and usage patterns of social media on student communication and non-communication, meaning there is no difference between them. While the level of media literacy among students of communication and noncommunication there is a difference, where students have the communication level of awareness and understanding better than students of non-communication. This is naturally the case given that social science clusters do have a lot to do with social matters such as reading, writing, interacting and socializing rather than being in a laboratory or doing something technical.

\section{CONCLUSION}

In this study, can be found the fact that the level of media literacy both students of communication and non-communication is at a medium level. While the pattern of use of social media both on student communication and non-communication is at a high level. Meanwhile, there is a significant relationship between media literacy and social media usage patterns in student communication and non-communication Amikom University Yogyakarta. Besides there is a difference in media literacy and social media usage patterns in student communication and non-communication at the University of Amikom Yogyakarta. This study is tiny in all its scope, so the suggestion of researchers is their advanced research on the relationship of media literacy levels to use social media not only on student communication and non-communication only, but may include majors broader and broader area, so it will be found the novelty of research results that will mostly benefit the community and can be used as reference material or reference for other research. Hopefully, this research can give an idea of the importance of understanding media literacy as one of the filters in the use of social media that has been 
contaminated with a variety of information hoaxes.

\section{ACKNOWLEDGMENT}

Acknowledgment are conveyed to communication and non-communication students in University of Amikom Yogyakarta who are willing to be respondents in this research. Mr. Suyanto who has become a partner to finishing this research, as well as the University of Amikom Yogyakarta which has supported, helped and facilitated the process until the end of the report

\section{REFERENCES}

Apperly, I.A., (2012). What is "theory of mind"? Concepts, cognitive processes and individual differences. Q. J. Exp. Psychol. 65, 825-839.

Baym, N.K., (2015). Personal connections in the digital age. John Wiley \& Sons.

Baym, N.K., Zhang, Y.B., Kunkel, A., Ledbetter, A., Lin, M.-C., (2007). Relational quality and media use in interpersonal relationships. New Media Soc. 9, 735-752.

Berthon, P.R., Pitt, L.F., Plangger, K., Shapiro, D., (2012). Marketing meets Web 2.0, social media, and creative consumers: Implications for international marketing strategy. Bus. Horiz. 55, 261271.

Brutus, S., Donia, M.B., (2010). Improving the effectiveness of students in groups with a centralized peer evaluation system. Acad. Manag. Learn. Educ. 9, 652-662.

Dabbagh, N., Kitsantas, A., (2012). Personal Learning Environments, social media, and self-regulated learning: A natural formula for connecting formal and informal learning. Internet High. Educ. $15,3-8$.

DeFleur, M.L., DeFleur, M.H., (2016). Mass communication theories: Explaining origins, processes, and effects. Routledge.
Digital in (2018): World's internet users pass the 4 billion mark - We Are Social [WWW Document], n.d. URL https:// wearesocial.com/blog/2018/o1/globaldigital-report-2018 (accessed 10.2.18).

Dimmick, J., Ramirez Jr, A., Wang, T., Lin, S.F., (2007). Extending society': The role of personal networks and gratificationutilities in the use of interactive communication media. New Media Soc. 9, 795-810.

Fuchs, C., 2017a. Social media: A critical introduction. Sage.

Fuchs, C., 2017b. Social media: A critical introduction. Sage.

Gross, J.J., John, O.P., (2003). Individual differences in two emotion regulation processes: implications for affect, relationships, and well-being. J. Pers. Soc. Psychol. 85, 348.

Kaplan, A.M., Haenlein, M., (2010). Users of the world, unite! The challenges and opportunities of Social Media. Bus. Horiz. 53, 59-68.

Katz, E., (2010). On sixty years of research and theorizing on mass communication. Rev. Rom. Jurnalism Si Comun. 5, 5.

Kilian, T., Hennigs, N., Langner, S., (2012). Do Millennials read books or blogs? Introducing a media usage typology of the internet generation. J. Consum. Mark. 29, 114-124.

Koltay, T., 2011. The media and the literacies: Media literacy, information literacy, digital literacy. Media Cult. Soc. 33, 211-221.

Lenhart, A., Purcell, K., Smith, A., Zickuhr, K., (2010). Social Media \& Mobile Internet Use among Teens and Young Adults. Millennials. Pew Internet Am. Life Proj.

Literat, I., (2014). Measuring New Media Literacies: Towards the Development of a Comprehensive Assessment Tool. J. Media Lit. Educ. 6, 15-27.

Media, K.C., (2018). Riset Ungkap Pola 
Pemakaian Medsos Orang Indonesia [WWW Document]. KOMPAS.com. URL https://tekno.kompas.com/ $\mathrm{read} / 2018 / 03 / 01 / 10340027 / \mathrm{riset}-$ ungkap-pola-pemakaian-medsosorang-indonesia (accessed 10.2.18).

O'Keeffe, G.S., Clarke-Pearson, K., (2011). The impact of social media on children, adolescents, and families. Pediatrics $127,800-804$.

Pike, S., Ryan, C., (2004). Destination positioning analysis through a comparison of cognitive, affective, and conative perceptions. J. Travel Res. 42, 333-342.

Potter, W.J., (2013). Media literacy. Sage Publications.

Potter, W.J., (2010). The state of media literacy. J. Broadcast. Electron. Media 54, 675-696.

Quan-Haase, A., Young, A.L., (2010). Uses and gratifications of social media: A comparison of Facebook and instant messaging. Bull. Sci. Technol. Soc. 30, 350-361.

Riset Ungkap Pola Pemakaian Medsos Orang Indonesia - Badan Litbang [WWW Document], n.d. URL http://litbang. kemendagri.go.id/website/risetungkap-pola-pemakaian-medsosorang-indonesia/ (accessed 10.2.18).

Ruggiero, T.E., (200o). Uses and gratifications theory in the 21st century. Mass Commun. Soc. 3, 3-37.

Silverblatt, A., Miller, D.C., Smith, J., Brown, N., (2014). Media Literacy: Keys to Interpreting Media Messages: Keys to Interpreting Media Messages. ABCCLIO.

Smith, B.L., Lasswell, H.D., (2015). Propaganda, communication and public opinion. Princeton university press.

Smock, A.D., Ellison, N.B., Lampe, C., Wohn, D.Y., (2011). Facebook as a toolkit: A uses and gratification approach to unbundling feature use. Comput. Hum. Behav. 27, 2322-2329.

Urista, M.A., Dong, Q., Day, K.D., (2009). Explaining why young adults use MySpace and Facebook through uses and gratifications theory. Hum. Commun. 12, 215-229.

Youmans, W.L., York, J.C., (2012). Social media and the activist toolkit: User agreements, corporate interests, and the information infrastructure of modern social movements. J. Commun. 62, 315-329. 